\title{
A Comparison Between Backpropagation, Holt-Winter, and Polynomial Regression Methods in Forecasting Dog Bites Cases in Bali
}

\author{
Gede Eridya Bayu Seyoga ${ }^{\mathrm{a} 1}$, I Ketut Gede Darma Putra ${ }^{\mathrm{a} 2}$, Ni Kadek Dwi Rusjayanthi ${ }^{\mathrm{a}}$ \\ ${ }^{a}$ Department of Information Technology, Engineering Faculty, Udayana University Bukit \\ Jimbaran, Bali, Indonesia, telp. +62087761213129 \\ e-mail: ${ }^{1}$ bayuseyoga19@gmail.com, ${ }^{2}$ ikgdarmaputra@unud.ac.id, ${ }^{3}$ dwi.rusjayanthi@unud.ac.id
}

\begin{abstract}
Abstrak
Rabies merupakan penyakit yang dapat menyebabkan kerusakan parah pada sistem saraf pusat dan umumnya berakibat fatal. Rabies biasanya menyebar melalui kontak dengan mamalia. Gigitan anjing merupakan penyebab utama penularan rabies di Bali, sehingga diperlukan penanganan yang cepat dan tepat untuk menekan angka kasus yang terjadi. Data mining adalah upaya untuk mengekstrak pengetahuan dari sekumpulan data. Menggunakan data mining untuk meramalkan kasus gigitan anjing berdasarkan data yang relevan dan model matematika. Metode data mining yang digunakan dalam peramalan kasus gigitan anjing adalah metode backpropagation, holt-winter, regresi polinomial. Penelitian ini bertujuan untuk memudahkan pemerintah dalam menyiapkan sarana pencegahan kasus gigitan anjing di Bali. Penelitian dilakukan dengan menggunakan data kasus gigitan anjing di Bali setiap bulan selama lima tahun, dari tahun 2015 hingga 2019. Data kasus gigitan anjing dibagi menjadi empat dataset berdasarkan masing-masing atribut, $80 \%$ sebagai data latih dan $20 \%$ sebagai data uji. Metode backpropagation mendapatkan akurasi tertinggi dengan rata-rata tingkat kesalahan MAPE 11,59\%. Sebagai perbandingan, metode holt-winters memiliki rata-rata tingkat kesalahan MAPE sebesar $16,05 \%$, dan metode regresi polinomial memiliki rata-rata tingkat kesalahan MAPE sebesar 19,91\%.
\end{abstract}

Kata kunci: Backpropagation, Gigitan Anjing, Holt-Winter, Peramalan, Rabies, Regresi Polinomial

\begin{abstract}
Rabies is a disease that can cause severe damage to the central nervous system and is generally fatal. Rabies is usually spread through contact with mammals. Dog bites are the leading cause of rabies transmission in Bali, so that fast and appropriate treatment is needed to reduce the number of cases that occur. Data mining is an attempt to extract knowledge from a set of data. Using data mining is to forecast dog bite cases based on relevant data and mathematical models. Data mining methods used in forecasting dog bite cases are backpropagation, holt-winters, polynomial regression methods. The research aims to facilitate the government in preparing means of preventing dog bite cases in Bali. The study was conducted using data on dog bite cases in Bali every month for five years, from 2015 to 2019. Dog bite case data is divided into four datasets based on each attribute, $80 \%$ as training data and $20 \%$ as test data. The backpropagation method gets the highest accuracy with an average MAPE error rate of $11.59 \%$. For comparison, the holt-winters method has an average MAPE error rate of $16.05 \%$, and the polynomial regression method has an average MAPE error rate of $19.91 \%$.
\end{abstract}

Keywords : Dog Bites, Rabies, Forecasting, Backpropagation, Holt-Winter, Polynomial Regression

\section{Introduction}

Rabies is a disease that can cause severe damage to the central nervous system and is generally fatal. Rabies is usually spread through contact with mammals, and dog bites are 
among the main factors transmitting rabies to humans [1]. Dog bite cases are considered one of the leading causes of rabies transmission in Bali Province, so prompt and precise action is needed to handle the increasing number of dog bite cases not to spread quickly and cause casualties. Data mining is an attempt to extract knowledge from a set of data [2]. The purpose of using data mining is to forecast dog bite cases based on relevant data and mathematical models [3].

Forecasting data on dog bite cases uses data in the form of time series. Backpropagation, holt-winter, and polynomial regression methods are often used in forecasting data in the form of time series. Backpropagation merupakan metode jaringan syaraf tiruan yang memiliki arsitektur multilayer yang digunakan untuk melakukan pelatihan berulang agar mendapatkan model arsitektur terbaik [4]. The holt-winters method is one of the exponential smoothing methods, namely triple exponential smoothing, which combines simple smoothing series, trend effects, and seasonal effects. This method is used to overcome forecasting in times series data that has trend and seasonal indicators. The holt-winters method, a combination of the holt method and the winters method, is superior to other exponential forecasting models $[5,6]$. The Polynomial Regression method is the value of the dependent variable in rising or falling linearly or occurring parabolically if the data is made in a scatter plot (the relationship between the dependent and independent variables is quadratic) and is a nonlinear regression method [7].

Forecasting is done using one of the applications for data mining, namely Rapidminer. Rapidminer is an open-source application used for data mining. Rapidminer offers a welldesigned user interface that allows the user to connect the respective operators used to each other in a process view. The data mining process in Rapidminer is divided into four different phases, namely, retrieving is the process of recovering data used for processing from specific data sources, preprocessing is a process to prepare or enrich the data taken to suit the needs for data mining, modelling is a process where The data that has been designed is used to extract or create a model that can be used to analyze previously unknown data, and evaluation is the process of measuring the performance of the model that has been made [8].

Several studies that have predicted rabies cases in dogs include research on predicting rabies in dogs in Thailand by Anchaleeporn Paso using the SARIMA method on rabies case data in Thailand from 2013 to 2017 [9]. Another study, namely analysis of forecasting data in the form of time series on rabies cases in China by Jian-Ping REN using the ARIMA method on rabies case data in China from 2004 to 2015 [10]. Research on comparative forecasting with the Backpropagation Neural Network and ARIMA methods to predict building materials' inventory stock. The Backpropagation Neural Network method produces better accuracy values than ARIMA [11]. Another study compares forecasting with the Holt-Winters and ARIMA methods on the number of foreign tourist arrivals to Bali Ngurah Rai in 2010-2015. The Holt-Winter method produces better accuracy values than ARIMA [12]. Forecasting of Electricity Consumption in Nigeria Using Regression Models resulting from the quadratic (polynomial) regression method produces higher accuracy than another regression method [13].

Based on research that has been done that the backpropagation and holt-winter forecasting methods have better accuracy results than other time series forecasting methods, such as the ARIMA method and polynomial regression method have better accuracy results than linear regression method, this is the author's basis in determining the method used for dog bite case data in Bali Province. The methods used are backpropagation, holt-winters, and polynomial regression. Four datasets were taken from each of the attributes in the dog bite data, the use of four datasets aimed to see the level of accuracy in the three methods with different data forms. The accuracy of the forecasting results in each method is calculated using the mean absolute deviation (MAD), which is a method used to measure the error rate in a forecasting method by calculating the number of absolute error and mean absolute percentage errors (MAPE), namely the method used to measure the level error or error in a forecasting method with the absolute error technique in each period divided by the real observed value for that period [14]. The research aims to facilitate the government in preparing means of preventing dog bite cases in Bali, such as the stray dog capture program and provide an adequate number of vaccines for bite victims. 


\section{Research Method}

The research methodology describes the stages of research that carry forecasting the dog bites case data. The general description of this research is depicted in an available chart that explains the steps carried out in the forecasting process. Figure 1 is an overview of this research.

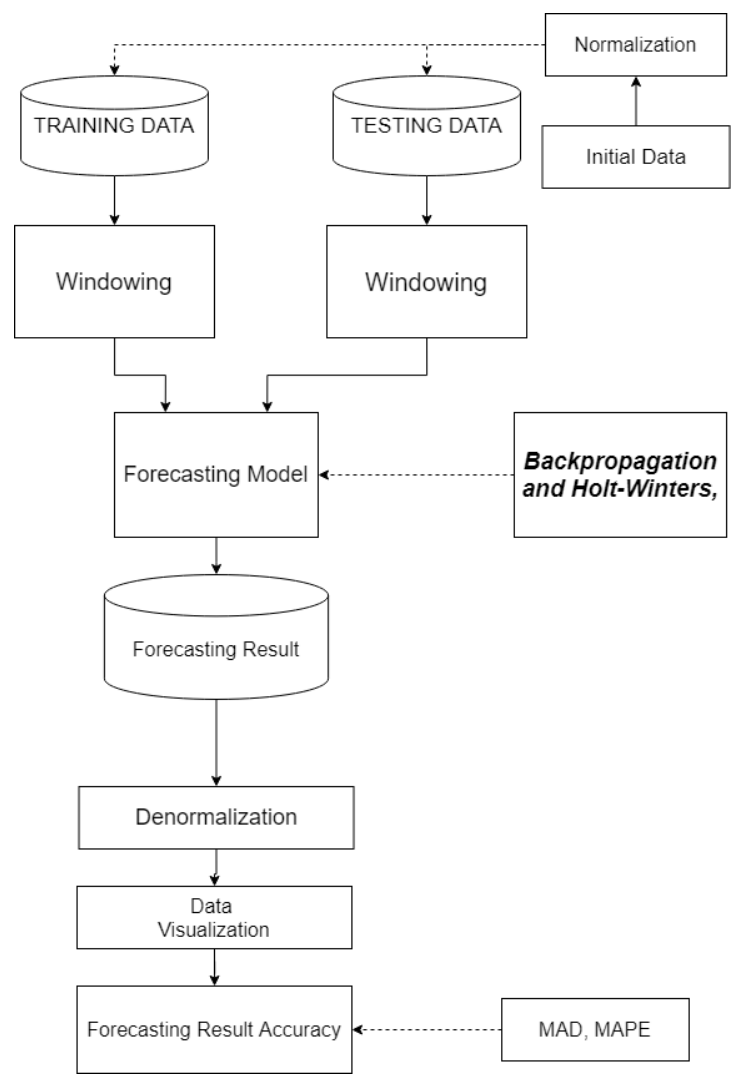

Figure 1. Research Overview

\subsection{Data}

The data collection process was carried out at the Bali Provincial Health Office. Data on dog bite cases every month from 2015 to 2019 consists of four attributes: dog bite cases, the number of vaccinations for dog bites, the number of male deaths, and the number of female deaths, where these data are the basis for the prediction process. Dog bite case data is divided into four datasets based on each attribute, $80 \%$ as training data and $20 \%$ as test data.

\subsection{Data Normalization}

Data normalization is a data transformation technique that eliminates data redundancies and converts them into easier-to-understand values. Normalization is essential in handling time series data because time series data have different ranges and units. The normalization process helps make numerical calculations more precise and improves the accuracy of forecast results. The normalization process is carried out for each attribute in the dog bite case data before inputting the Rapidminer application. Formula 1 is an equation used for min-max normalization [15].

$$
v^{I}=\frac{v-\min _{A}}{\max _{A}-\min _{A}}
$$

Where :

$\mathrm{V}^{\prime} \quad=$ normalized data 
$\begin{array}{ll}v & =\text { initial data } \\ \min _{\mathrm{A}} & =\text { lowest data value } \\ \max _{\mathrm{A}} & =\text { highest data value }\end{array}$

\subsection{Data Training and Data Testing}

Data that serves as the basis of a forecast and is based on facts is called training data, while data that functions to measure the accuracy of forecasting is called test data. The four datasets for each attribute of dog bite case data were divided into 2: training data and testing data with a division ratio of 4 years of training data $(80 \%)$ and one year of testing data $(20 \%)$ before being entered Rapidminer.

\section{$2.4 \quad$ Windowing}

This study uses windowing operators on dog bite case data, which improves the accuracy of forecasting the data in time series. Figure 2 shows an overview of the windowing operator process [16].
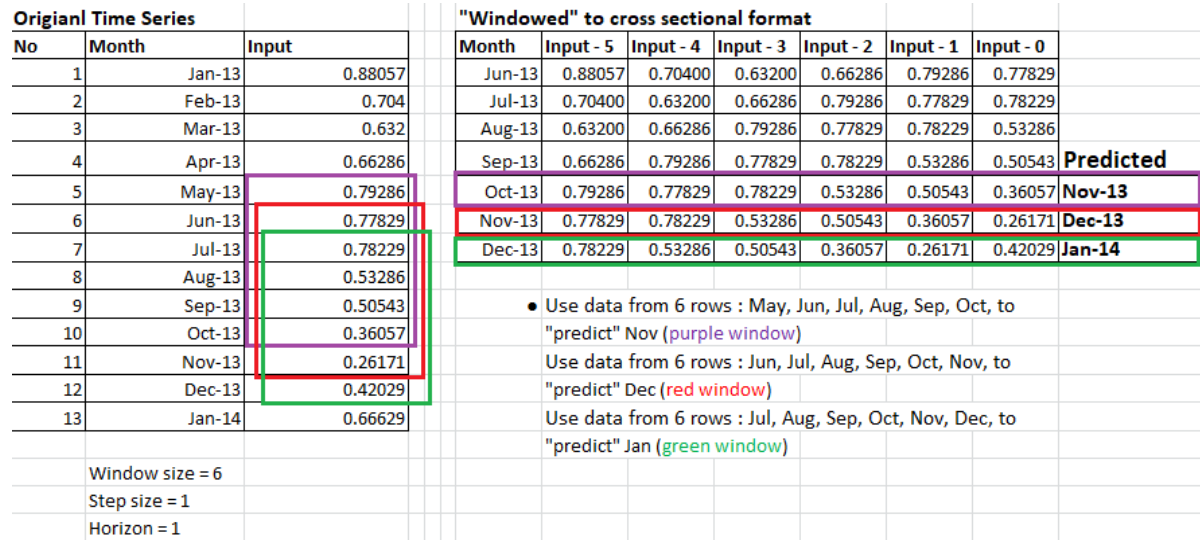

Figure 2. Windowing Operator

The windowing operator functions to convert the time series data into a horizontal form to increase the number of inputs entered into the forecasting model to improve the accuracy in forecasting data in time series. Windowing converts several time series data as much as the window size into input values to predict future values. There are three main stages in making windowing, first determining the size of windows (window size), determine the number of line steps to create the next window (step size), and determine how long the future value forecast is (horizon).

\subsection{Forecasting Model}

Forecasting models are created using the Rapidminer 9.2 tools. Operators in Rapidminer 9.2 can be used in making the desired forecasting model. This study uses a forecasting model using the backpropagation neural network, holt-winter (triple exponential smoothing), and polynomial regression methods. Figure 3, Figure 4, Figure 5 shows an overview of the forecasting model made with the backpropagation, holt-winters, and the polynomial regression method in Rapidminer 9.2.

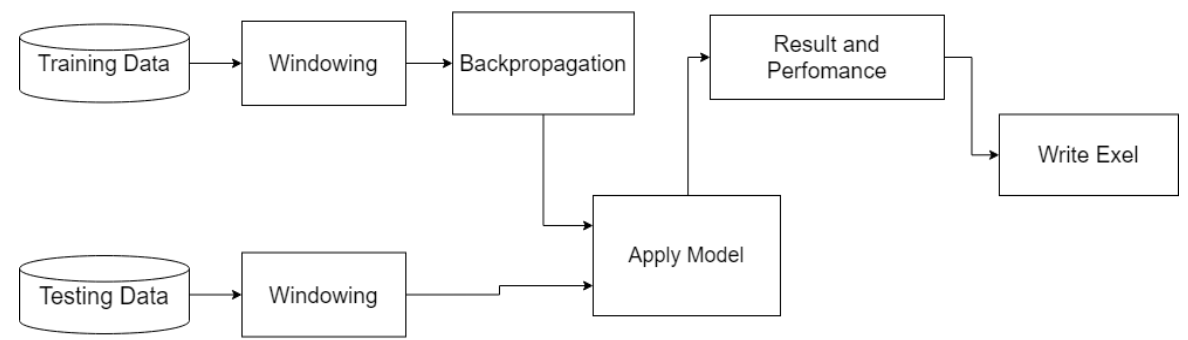

Figure 3. Forecasting Model for Backpropagation Method 
Figure 3 shows an overview of the forecasting model's appearance created in Rapidminer 9.2 using the Backrpropagation data mining method. The operators in the forecasting model above are as follows, retrieve data, windowing, model (backpropagation), apply model, result \& performance, and conversion (excel).

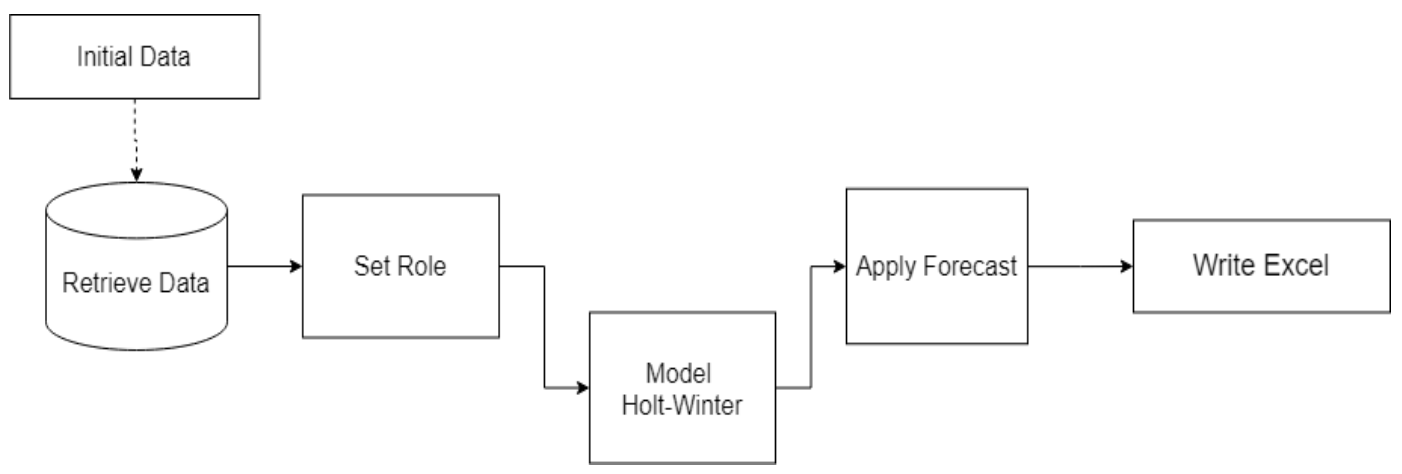

Figure 4. Forecasting Model for Holt-Winter Method

Figure 4 shows an overview of the forecast model created in Rapidminer 9.2 using the Holt-Winter data mining method. The operators in the forecasting model above are as follows, retrieve data, set role, model (holt-winter), apply forecast, and conversion (excel).

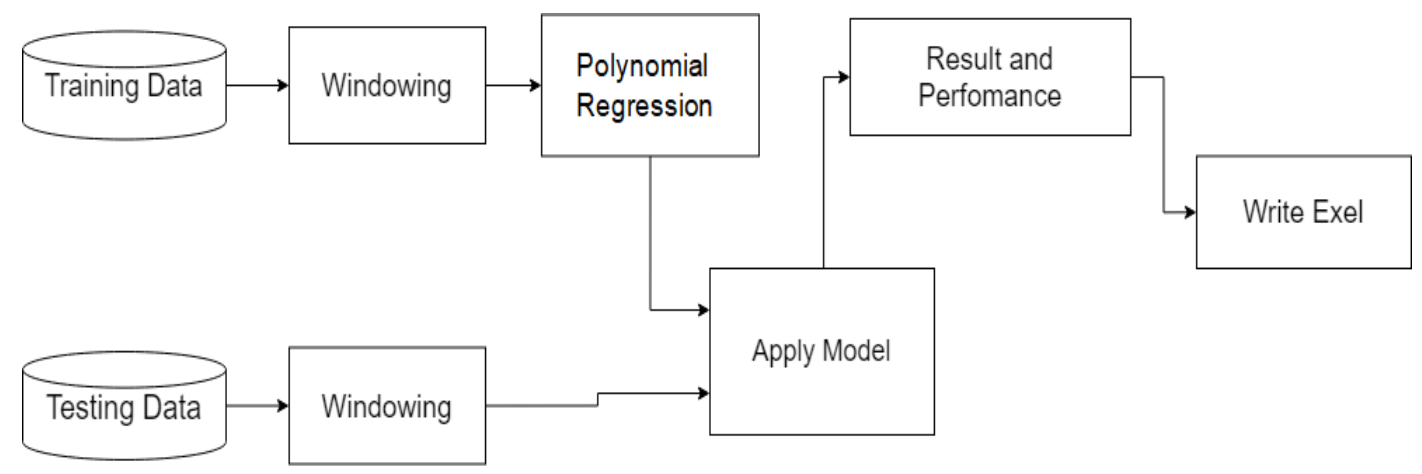

Figure 5. Forecasting Model for Polynomial Regression Method

Figure 3 shows an overview of the forecasting model's appearance created in Rapidminer 9.2 using the polynomial regression data mining method. The operators in the forecasting model above are as follows, retrieve data, windowing, model (polynomial regression), apply model, result \& performance, and conversion (excel).

\subsection{Forecasting Result}

The forecasting results that have been obtained depending on the forecasting model used. Forecasting results containing forecasts from the test data will be visualized using a line graph. Forecasting results in this study have an integer data type, namely as follows. The forecasting results that have been obtained will vary depending on the forecasting model used. Forecasting results containing forecasts from the test data will be visualized using a line graph. Data visualization is done to make it easier to understand the data that used in forecasting. The visualization used in this research is in the form of graphics created using tools in Microsoft Excel. The data graph serves to make it easier to interpret the results of the forecasting.

\subsection{Denormalization}

The denormalization process functions to return the data value to its original form after the normalization process to be easier to understand. The denormalization process is carried out with the equation in Formula 2 [17]

$$
v=v^{g}\left(\max _{A}-\min _{A}\right)+\min _{A}
$$




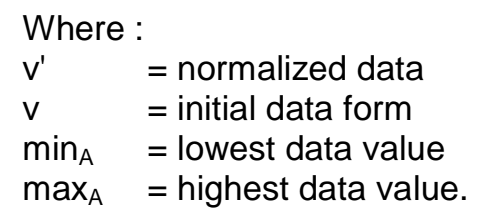

\subsection{Forecasting Result Accuracy}

Several methods have been used to show the mistakes caused by specific forecasting techniques. Almost all of these measures use several averaging functions of the difference between the actual data and the predicted data. The difference between the actual data and the forecast data is usually referred to as the residual. One way of evaluating forecasting techniques is to measure how the difference between forecast results and actual data occurs [18]. This study uses two measures: Mean Absolute Deviation (MAD) and Mean Absolute Percentage Error (MAPE). Formula 3 shows the MAD equalition[19].

$$
M A D=\frac{\sum\left(X_{i}-F_{i}\right)}{n}
$$

Where :

$X_{\mathrm{i}} \quad=$ initial data,

$F_{\mathrm{i}} \quad=$ forecasting data, and

$\mathrm{n} \quad=$ number of data.

MAPE provides information on the percentage of too high or too low errors. The smaller the MAPE percentage value, the higher the accuracy of the forecasting. Formula 4 shows the MAPE equalition [19].

$$
\text { MAPE }=\frac{\sum \frac{\left|X_{i}-F_{i}\right|}{X_{i}}}{n} \times 100 \%=\frac{\sum \frac{\| E_{i} \mid}{X_{i}}}{n} \times 100 \%
$$

Where :

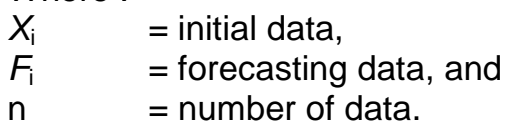

\section{Literature Study}

The literature study contains material that is the research reference. The selection of reference materials used is adjusted to the topic of the research being carried out. The issue of this research is predicting dog bite case data. The references included are dog bites and rabies, data mining, forecasting, rapidminer, backpropagation, holt-winter, and polynomial regression.

\subsection{Rabies}

Rabies is a disease that can cause severe damage to the central nervous system and is generally fatal. Rabies is usually spread through contact with mammals, and dog bites are among the main factors in transmitting rabies to humans. This disease is classified as very dangerous because it has a great potential to cause death. Early rabies such as fever, muscle weakness, and tingling usually appear four to twelve weeks after an infected animal has bitten the victim. Dog bites are one of the main factors in transmitting rabies to humans [1].

\subsection{Data Mining}

Data mining attempts to extract knowledge from a set of data to find patterns or relationships contained in that data set. The data mining process describes knowledge in the database. Data mining can be described as knowledge mining from a collection of data sets, word mining in data mining is defined as the process of finding a small collection of useful information or patterns from a material (data set) [20]. The use of the data mining process is to extract and identify useful information and further knowledge. The use of data mining is very well used in various data processing activities such as classification, clustering, association, and prediction, making it possible to describe trends in data and predict the value of future data [2]. 


\subsection{Forecasting}

Forecasting is a data processing process by using some of the value data in a data set to find patterns or information to predict the next value in the future. Forecasting can be used in various fields, namely business, economics, politics, social, medicine, and finance. Forecasting problems often encountered are classified into three types: short term, medium-term, and long term. Short-term forecasting involves predicting data for some period of time (days, weeks, months) in the future, medium-term forecasting includes predicting data for the next one to two years, and long-term forecasting includes predicting data over the next several years (five to ten years) [21].

\subsection{Backpropagation}

Backpropagation is one of the methods in artificial neural networks. The backpropagation method is very well used in the application process of forecasting and pattern recognition. Rumelhart, Hinton, and William were the first to introduce the backpropagation method into the world of data mining in 1986, and then the backpropagation method was developed by Rumelhart and McClelland in 1988. In developing artificial neural networks, many use the backpropagation method because backpropagation is a multilayer network so that the backpropagation network architecture can be used to perform learning and analysis on a data pattern in the data set more precisely and get more accurate results (minimum error) [22].

\subsection{Holt-Winter}

The HoltWinters method is a triple exponential smoothing that combines simple smoothing series, trend effects, and seasonal effects. The accuracy of forecasting from this method reflects the suitability of reality, assuming that the data follows several historical patterns. The more observations or data used, the more relevant it is in predicting the future. The Holt-Winters method is superior to the simple exponential model and the naïve base model forecasting [23].

\subsection{Polynomial Regression}

The Polynomial Regression model has been widely used in various data processing processes in computer science, engineering, human resources, and health. The Polynomial Regression method is the value of the dependent variable in rising or falling linearly or occurring parabolically if the data is made in a scatter plot (the relationship between the dependent and independent variables is quadratic) and is a non-linear regression method [24].

\subsection{Rapidminer}

Rapidminer is an open-source application used for data mining. Rapidminer offers a well-designed user interface that allows the user to connect the respective operators used to each other in a process view. The data mining process in Rapidminer is divided into four different phases, namely, retrieving is the process of recovering data used for processing from specific data sources, preprocessing is a process to prepare or enrich the data taken to suit the needs for data mining, modelling is a process where The data that has been designed is used to extract or create a model that can be used to analyze previously unknown data, and evaluation is the process of measuring the performance of the model that has been made [25].

\section{Result and Discussion}

The prediction was carried out on the dog bite causal data. The Backpropagation and Holt-Winter forecasting methods are used to predict the four attributes contained in dog bite data, namely the number of cases of dog bites, the number of vaccinations against victims, the number of male deaths, and the number of female deaths. Different parameter architectures are applied to each forecasting model used in both methods to obtain the best forecasting results.

\section{1. $\quad$ Forecasting Result}

The results of forecasting dog bite case data with different parameter architectures were used in each model tested on the backpropagation, holt-winter, and polynomial regression method. The level of accuracy in each method is as follows. 
Table 3. Forecasting Accuracy on Backpropagation Method

\begin{tabular}{ccccccc}
\hline \multirow{2}{*}{ Model } & $\begin{array}{c}\text { Learning } \\
\text { Rate }\end{array}$ & $\begin{array}{c}\text { Hidden } \\
\text { Layer }\end{array}$ & Neuron & & \multicolumn{3}{c}{ Result } \\
\cline { 5 - 7 } & & & & Epoch & MAD & MAPE \\
\hline Model 1 & 0.03 & 1 & 4 & 100 & 344.62 & $14.14 \%$ \\
\hline Model 2 & 0.03 & 1 & 4 & 200 & 172.42 & $6.88 \%$ \\
\hline Model 3 & 0.03 & 1 & 5 & 300 & 219.09 & $8.88 \%$ \\
\hline Model 4 & 0.03 & 1 & 5 & 400 & 230.86 & $9.36 \%$ \\
\hline
\end{tabular}

Table 3 shows the prediction accuracy results on the attribute dog bite cases using a backpropagation method. This architecture used one hidden layer with neurons 4 and 5 . This study's learning rate is 0.3 , and the epoch value used is 100 to 400 . Model 2 shows that architecture backpropagation with hidden layer 1 , number of neurons 4 , learning rate 0.3 , and epoch 200 has the lowest error value. The MAD value in the model 2 architecture is 172.42 , and the percentage error (MAPE) is $6.88 \%$. The results obtained from model 2 architecture can be seen in Table 4.

Tabel 4. Forecasting Result the Number of Dog Bite Cases using the Backpropagation Method

\begin{tabular}{ccccc}
\hline \multicolumn{5}{c}{ Backpropagation Method } \\
\hline Month & Initial Data & Forecasting Data & MAD & MAPE \\
\hline Feb-2019 & 2448 & 2591 & 143 & $5.84 \%$ \\
Mar-2019 & 2325 & 2407 & 82 & $3.51 \%$ \\
Apr-19 & 2495 & 2344 & 151 & $6.04 \%$ \\
May-2019 & 2373 & 2457 & 84 & $3.53 \%$ \\
June-2019 & 2511 & 2400 & 111 & $4.40 \%$ \\
July-2019 & 3104 & 2535 & 569 & $18.32 \%$ \\
Agt-2019 & 2714 & 2520 & 194 & $7.15 \%$ \\
Sep-19 & 2501 & 2533 & 32 & $1.28 \%$ \\
Okt-2019 & 2455 & 2543 & 88 & $3.59 \%$ \\
Nov-19 & 2239 & 2368 & 129 & $5.76 \%$ \\
Des-2019 & 1941 & 2256 & 315 & $16.23 \%$ \\
& & & \\
\hline
\end{tabular}

Table 4 compares actual data and forecasting data of dog bite cases using a backpropagation method. Table 4 shows the forecasting results of forecasting data, MAD values, and the percentage error (MAPE) values each month. Forecasting accuracy in 2019 is obtained by calculating the average percentage error (MAPE) values each month. The average MAPE value obtained is $6.88 \%$, so the forecasting accuracy using the backpropagation model 2 method on dog bite case data in 2019 is $95.12 \%$.

Table 5. Forecasting Accuracy on Holt-Winter Method

\begin{tabular}{lcccccc}
\hline \multirow{2}{*}{ Model } & \multirow{2}{*}{ Period } & \multirow{2}{*}{ Alpha } & \multirow{2}{*}{ Beta } & \multirow{2}{*}{ Gamma } & \multicolumn{2}{c}{ Result } \\
\cline { 7 - 8 } & & & & & MAD & MAPE \\
\hline Model 1 & 3 & 0.7 & 0.1 & 0.7 & 227.64859 & $9.36 \%$ \\
\hline Model 2 & 3 & 0.8 & 0.1 & 0.7 & 224.98751 & $9.22 \%$ \\
\hline
\end{tabular}




\begin{tabular}{lllllll} 
Model 3 & 4 & 0.7 & 0.1 & 0.7 & 221.3257 & $9.02 \%$ \\
\hline Model 4 & 4 & 0.8 & 0.1 & 0.8 & 232.43407 & $9.61 \%$ \\
\hline
\end{tabular}

Table 5 shows the prediction accuracy results on the attribute dog bite cases using a holt-winters method. This architecture used 3 and 4 periods with Alpha values (0.7 and 0.8$)$, Beta 0.1, Gamma (0.7 and 0.8). Model 3 shows that in the holt-winters architecture with period 4 , the number of values for alpha is $0.7,0.1$ for beta, and 0.7 for gamma, which has the lowest error value. The MAD value in the model 3 architecture is 221.3257 , and the percentage error (MAPE) is $9.02 \%$. The results obtained from model 3 architecture can be seen in Table 6 .

Table 6. Forecasting Result the Number of Dog Bite Cases using the Holt-Winter Method

\begin{tabular}{ccccc}
\hline \multicolumn{5}{c}{ Holt-Winters Method } \\
\hline Month & $\begin{array}{c}\text { Initial } \\
\text { Data }\end{array}$ & $\begin{array}{c}\text { Forecasting } \\
\text { Result }\end{array}$ & MAD & MAPE \\
\hline Jan-2019 & 2285 & 2588.141164 & 303.1411637 & $13.27 \%$ \\
Feb-2019 & 2448 & 2639.222184 & 191.2221841 & $7.81 \%$ \\
Mar-2019 & 2325 & 2712.3685 & 387.3685003 & $16.66 \%$ \\
Apr-19 & 2495 & 2552.062696 & 57.06269611 & $2.29 \%$ \\
May-2019 & 2373 & 2455.487441 & 82.48744063 & $3.48 \%$ \\
June-2019 & 2511 & 2494.975517 & 16.02448323 & $0.64 \%$ \\
July-2019 & 3104 & 2552.558207 & 551.4417928 & $17.77 \%$ \\
Agt-2019 & 2714 & 2410.038053 & 303.9619471 & $11.20 \%$ \\
Sep-19 & 2501 & 2322.833718 & 178.1662824 & $7.12 \%$ \\
Okt-2019 & 2455 & 2350.728849 & 104.2711505 & $4.25 \%$ \\
Nov-2019 & 2239 & 2392.747914 & 153.747914 & $6.87 \%$ \\
Des-2019 & 1941 & 2268.01341 & 327.0134097 & $16.85 \%$ \\
& \multicolumn{5}{c}{} & $9.02 \%$ \\
\hline
\end{tabular}

Table 6 compares actual data and forecasting data of dog bite cases using a holtwinters method. Table 6 shows the forecasting results of forecasting data, MAD values, and the percentage error (MAPE) values each month. Forecasting accuracy in 2019 is obtained by calculating the average percentage error (MAPE) values each month. The average MAPE value obtained is $9.02 \%$, so the forecasting accuracy using the holt-winters model 3 method on dog bite case data in 2019 is $90.98 \%$.

Table 7. Forecasting Accuracy on Polynomial Regression Method

\begin{tabular}{lcccccc}
\hline \multirow{2}{*}{ Model } & Max & Max & Coefficient & Coefficient & \multicolumn{2}{c}{ Result } \\
\cline { 2 - 7 } & Iteration & Degree & Min & Max & MAD & MAPE \\
\hline Model 1 & $\mathbf{6 0 0 0}$ & $\mathbf{3}$ & $\mathbf{- 1 0 0}$ & $\mathbf{1 0 0}$ & $\mathbf{1 9 7 . 5 1 6 6}$ & $\mathbf{7 . 7 5 \%}$ \\
\hline Model 2 & 7000 & 3 & -100 & 100 & 417.56667 & $17.62 \%$ \\
\hline Model 3 & 6000 & 4 & -100 & 100 & 206.10114 & $7.84 \%$ \\
\hline Model 4 & 7000 & 4 & -100 & 100 & 349.42243 & $14.60 \%$ \\
\hline
\end{tabular}

Table 7 shows the prediction accuracy results of dog bite cases attribute using a polynomial regression method. The Maximum Iteration values used in the study were 6000 and 7000 , maximum degree values ( 3 and 4 ), minimum coefficient values are -100 , maximum coefficient values are 100. Model 1 indicates that the Polynomial Regression architecture with 
the Maximum Iteration value used in the study is 6000 , the value of the Maximum Degree is 3 , the Minimum coefficient value is -100 , and the Maximum coefficient value is 100 has the lowest error value. The MAD value in the Model 1 architecture is 197.5166 , and the percentage error (MAPE) is $7.75 \%$. The results obtained from Model 1 architecture can be seen in Table 8 .

Table 8. Forecasting Result the Number of Dog Bite Cases using the Polynomial Regression Method

\begin{tabular}{ccccc}
\hline \multicolumn{5}{c}{ Polynomial Regression Method } \\
\hline \multirow{2}{*}{ Month } & $\begin{array}{c}\text { Initial } \\
\text { Data }\end{array}$ & $\begin{array}{c}\text { Forecasting } \\
\text { Result }\end{array}$ & MAD & MAPE \\
\hline Mar-2019 & 2325 & 2543.045961 & 218.0459613 & $9.38 \%$ \\
Apr-19 & 2495 & 2394.584502 & 100.4154977 & $4.02 \%$ \\
May-2019 & 2373 & 2357.026339 & 15.97366087 & $0.67 \%$ \\
June-2019 & 2511 & 2582.941858 & 71.94185807 & $2.87 \%$ \\
July-2019 & 3104 & 2443.703329 & 660.2966706 & $21.27 \%$ \\
Agt-2019 & 2714 & 2550.644998 & 163.3550015 & $6.02 \%$ \\
Sep-19 & 2501 & 2770.675844 & 269.675844 & $10.78 \%$ \\
Okt-2019 & 2455 & 2436.708096 & 18.2919038 & $0.75 \%$ \\
Nov-19 & 2239 & 2496.828866 & 257.8288656 & $11.52 \%$ \\
Des-2019 & 1941 & 2140.340326 & 199.3403265 & $10.27 \%$ \\
& \multicolumn{5}{c}{} & \\
\hline \multicolumn{7}{c}{ MAPE } \\
\hline
\end{tabular}

Table 8 compares actual data and forecasting data of dog bite cases using a polynomial regression method. Table 8 shows the forecasting results of forecasting data, MAD values, and the percentage error (MAPE) values each month. Forecasting accuracy in 2019 is obtained by calculating the average percentage error (MAPE) values each month. The average MAPE value obtained is $7.75 \%$, so the forecasting accuracy using the Polynomial Regression model 1 method on dog bite case data in 2019 is $92.25 \%$.

\subsection{Comparison of Forecasting Results}

Figure 9 and Figure 10 shows the final results of forecasting dog bite case data for each attribute with the best architecture on the backpropagation, holt-winters, and polynomial regression methods.

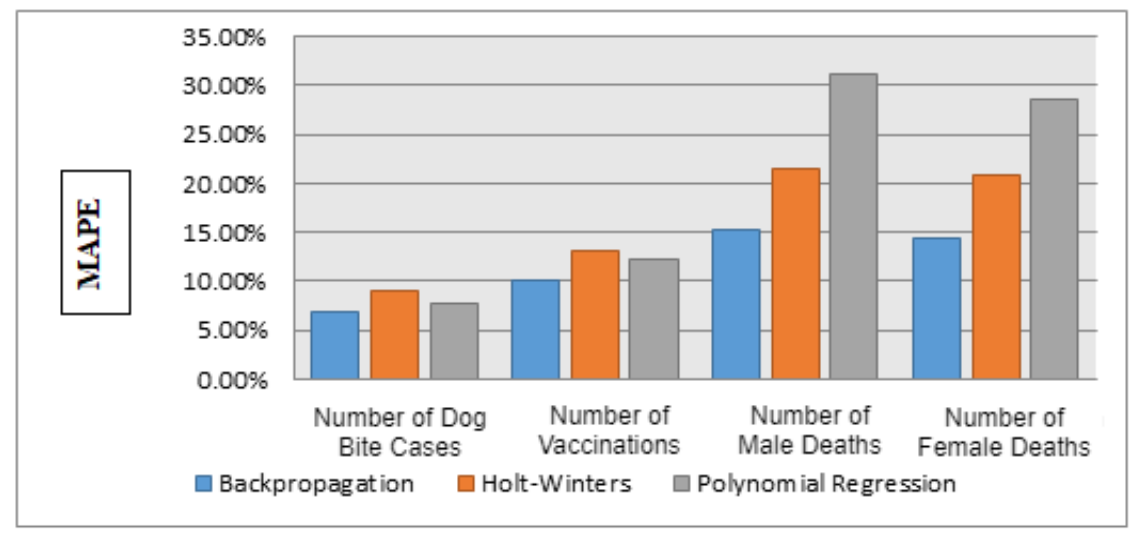

Figure 9. Chart of Forecasting Results of Dog Bite Case Data 
Figure 9 shows the forecast results for each attribute from the data on dog bite cases in Bali Province using the Backpropagation, Holt-Winters, and Polynomial Regression methods. The results obtained are derived from the best architecture for each method used in each attribute.

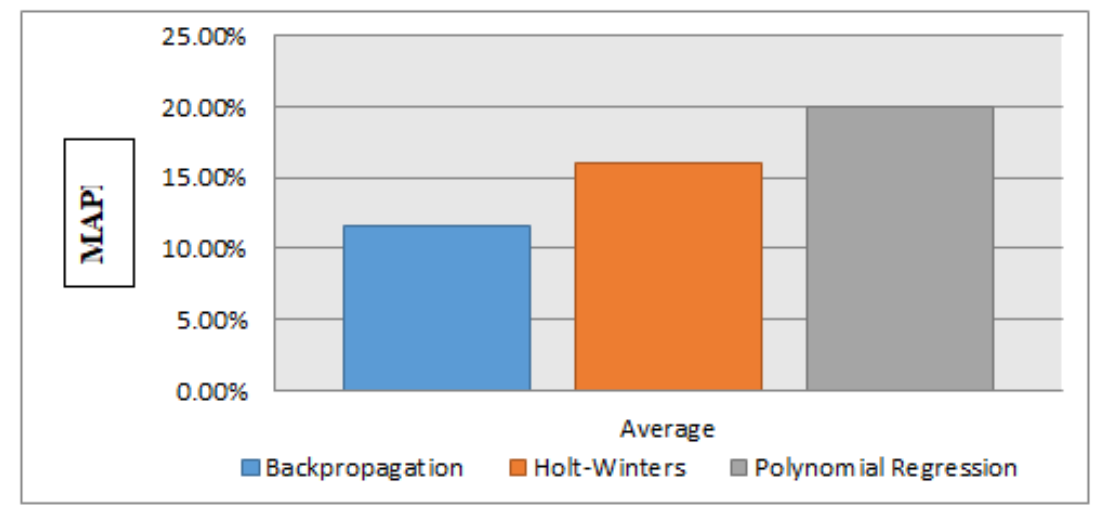

Figure 10. Comparison Chart of Backpropagation, Holt-Winter, and Polynomial Regression Method Error Rates

Figure 10 shows the average error value of each method on all attributes of the dog bite data. The backpropagation method has an error value of $11.59 \%$, the holt-winters method has an error value of $16.05 \%$, and the polynomial regression method has an error value of $19.91 \%$. The backpropagation method has better accuracy than the Holt-Winters and the polynomial regression method in predicting dog bites cases data in Bali.

\section{Conclusion}

The backpropagation method has better accuracy than the holt-winters and polynomial regression method in predicting dog bites cases data in Bali. The backpropagation method has a minor error percentage (MAPE) value of $11.59 \%$, the holt-winters method has an error percentage (MAPE) value of $16.05 \%$, and the polynomial regression method has an error percentage (MAPE) value of $19.91 \%$. Hope for future research is that additional methods and data updates will be carried out on the actual data to obtain more data to develop variations in the methods used and increase forecasting accuracy.

\section{References}

[1] A. C. Jackson, "Human Rabies: a 2016 Update," Current Infectious Disease Reports, vol. 18, p. 38, 2016/10/12 2016.

[2] Mirqotussa'adah, "Penerapan Dizcretization dan Teknik Bagging Untuk Meningkatkan Akurasi Klasifikasi Berbasis Ensemble pada Algoritma C4.5 dalam Mendiagnosa Diabetes " Lontar Komputer, vol. 8, 2017.

[3] A. Muqtadir, "The Implementation of Grey Forecasting Model for Forecast Result's Food Crop Agricultural," Scientific Journal of Informatics, vol. 3, 2016.

[4] S. P. Siregar, "Analysis of Artificial Neural Network Accuracy Using Backpropagation Algorithm In Predicting Process (Forecasting) " International Journal Of Information System \& Technology, vol. 1, 2017.

[5] D. A. Winarso, "Model Prediksi Kekeringan Menggunakan Metode Holt-Winters (Studi Kasus : Wilayah Kabupaten Boyolali)," Indonesian Journal of Computing and Modeling, vol. 1, pp. 36-41, 2018.

[6] A. Fahlevi, "Perbandingan Holt's dan Winter's Exponential Smoothing untuk Peramalan Indeks Harga Konsumen Kelompok Transportasi, Komunikasi dan Jasa Keuangan," Jurnal Pengembangan Teknologi Informasi dan IImu Komputer, vol. 2, pp. 6136-6145, 2018.

[7] Hall.G.Peter, "Infinite Order Cross-Validated Local Polynomial Regression," 2013.

[8] A. Kori, "Comparative Study of Data Classifiers Using Rapidminer," International Journal of Economics Development Research, vol. 5, 2017. 
[9] A. Paso, "Forecasting Rabies in Dogs in Thailand : Time Series Analysis," Naresuan University Journal : Science and Technology, vol. 28, 2020.

[10] J.-P. REN, "The time-series analysis of human rabies in China," Chinese Journal of Zoonoses, vol. 34, 2018.

[11] I. A. Soenandi, "A Comparison of Forecasting Building Material Inventory between Backpropagation Neural Network And Arima," IOP Conf. Series: Materials Science and Engineering, vol. 528, 2019.

[12] T. Safitri, "Perbandingan Peramalan Menggunakan Metode Eksponensial Holt-Winter Smoothing dan ARIMA," Unnes Journal of Mathematics, vol. 6, 2017.

[13] I. Amazuilo, "Modelling and Forecasting of Residential Electricity Consumption in Nigeria Using Multiple and Quadratic Regression Models " American Journal of Software Engineering and Applications, vol. 6, pp. 99-104, 2017.

[14] I. Yulian, "Penerapan Metode Trend Moment dalam Forecasting Penjualan Produk CV.RABBANI ASYISA," JURTEKSI, vol. 6, pp. 193-200, 2020.

[15] M. Madhiarasan, "A novel criterion to select hidden neuron numbers in improved back propagation networks for wind speed forecasting," Applied Intelligence, vol. 44, pp. 878893, 2016.

[16] M. Kolomizki. Dive into the World of Data Mining Part 2: Building a model.

[17] N. M. Ashar, "Penerapan Metode Extreme Learning Machine (ELM) Untuk Memprediksi Jumlah Produksi Pipa Yang Layak (Studi Kasus Pada PT. KHI Pipe Industries)," Jurnal Pengembangan Teknologi Informasi dan IImu Komputer, vol. 2, pp. 4621-4628 2018.

[18] C. L. Karmaker, "Determination of Optimum Smoothing Constant of Single Exponential Smoothing Method: A Case Study " International Journal of Research in Industrial Engineering, vol. 6, pp. 184-192, 2017.

[19] U. Khair, "Forecasting Error Calculation with Mean Absolute Deviation and Mean Absolute Percentage Error," International Conference on Information and Communication Technology, vol. 930, 2017.

[20] I. P. A. P. Wibawa, "Prediksi Partisipasi Pemilih dalam Pemilu Presiden 2014 dengan Metode Support Vector Machine," Jurnal IImiah Merpati (Menara Penelitian Akademika Teknologi Informasi), vol. 7, pp. 182-192, 2019.

[21] N. P. R. Apriyanti, "Peramalan Jumlah Kecelakaan Lalu Lintas Menggunakan Metode Support Vector Regression," Jurnal Ilmiah Merpati (Menara Penelitian Akademika Teknologi Informasi), vol. 8, pp. 72-80, 2020.

[22] P. Nabilla, "Prediksi Jumlah Permintaan Koran Menggunakan Metode Jaringan Syaraf Tiruan Backpropagation," Jurnal Pengembangan Teknologi Informasi dan IImu Komputer, 2018.

[23] A. Nazim, "A comparison between single exponential smoothing (SES), double exponential smoothing (DES), holt's (brown) and adaptive response rate exponential smoothing (ARRES) techniques in forecasting Malaysia population " Global Journal of Mathematical Analysis, vol. 2, 2014.

[24] A. Pwasong, "Forecasting crude oil production using quadratic regression and layer recurrent neural network models," presented at the AIP Conference Proceedings 1750, 2016.

[25] Mardalius, "Pemanfaatan Rapid Miner Studio 8.2 Untuk Pengelompokan Data Penjualan Aksesoris Menggunakan Algoritma K-Means," Jurnal Teknologi dan Sistem Informasi, 2018. 